\title{
CAI and Its Application in Rural Junior English Class
}

\author{
Xiaojun $\mathrm{He}^{1}$ \\ ${ }^{1}$ School of Foreign Languages, Leshan Normal University, China \\ Correspondence: Xiaojun He, School of Foreign Languages, Leshan Normal University, Leshan, Sichuan, China. \\ Tel: 86-139-8137-6137. E-mail: 1stchxj@qq.com
}

Received: August 2, $2015 \quad$ Accepted: September 12, $2015 \quad$ Online Published: September 15, 2015
doi:10.5539/elt.v8n11p11
URL: http://dx.doi.org/10.5539/elt.v8n11p11

\begin{abstract}
Superiority in developing students' listening, speaking, etc. This thesis explores how to provide a bett. In recent years, using multimedia is the direction of reform and main stream in English teaching. Compared with the traditional English teaching, multimedia-aided English teaching has its incomparable er environment for English teaching in rural junior school with the aid of multimedia and find some ways to improve teaching efficiency. It, based on the research done at home and abroad on the application of multimedia in English teaching, and on the description of the current situation of rural English teaching in China, analyzes how to apply multimedia in rural junior English teaching, and then presents some things to bear in mind when applying multimedia in teaching.
\end{abstract}

Keywords: rural junior, English teaching, multimedia-aided

\section{Introduction}

Recently, the science and technology has been developed rapidly. The development of modern information technology provides a foundation for the development of multimedia. Multimedia, a vocabulary associated with science, is a media that common people use more and more frequently in their daily life. People can see the use of multimedia in various fields such as entertainment, business, advertisements, scientific research, which makes life more colorful and much more convenient. Of course, it is no exception that the application of multimedia in education is common.

Chen Jiangxi (2009) said, "Learning theories in the past decade has expanded dramatically because of the introduction of the multimedia. Several lines of research have evolved. The possibilities for language and instruction are nearly endless." Although multimedia has been used in many fields, some people still have no sense of what multimedia is. In fact, multimedia is defined in different words. For example, multimedia, in the Oxford Advanced Learner's English-Chinese Dictionary, is defined as "Using sound, pictures, and film in addition to text on a screen". In Wikipedia, multimedia is defined as "a media and content that uses a combination of different content forms. Multimedia includes a combination of text, audio, still images, animation, video, or interactivity content form". Simply speaking, multimedia is an integrative media which is helpful to our comprehending information vividly.

However, although the equipment of multimedia is frequently installed in schools, teachers can not make proper use of it in English teaching, especially in rural junior English teaching. What is worse, in some rural junior schools, teachers still only use the traditional methods to teach English without paying attention to the importance of the application of multimedia in junior English teaching.

So this paper will explore how to provide a better environment for English teaching in rural junior school with the aid of multimedia and find some ways to improve teaching efficiency. To achieve the purpose, it will first briefly introduce the research done by scholars at home and abroad on the application of multimedia in English teaching, and then present the current situation of rural English teaching in China. After that, the thesis will focus on applying multimedia in rural junior English teaching, and then present some things to bear in mind when applying multimedia in teaching.

\section{Literature Review}

Nowadays, in the educational field, multimedia has been frequently used, especially in English teaching. And the 
application of multimedia in the teaching of English has been studied by many researchers and scholars.

Computer-aided language teaching is the primary stage of computer-aided English teaching, which roughly began in the 1960s. Stanford University began computer assisted instruction research as early as 1963 and successfully developed the IBM1500 teaching system with the cooperation of BIM company in 1966. The teaching system is used in many teaching courses, including foreign language courses (Zhao, 2006). In 1996, Chuan and Plass carried out the teaching experiment study on the students who have studied German for a year (Zhao, 2006), respectively using pictures, texts, videos to study the influence of multimedia on vocabulary learning. The study shows that the students master words and phrases with illustrations and voice better than those without illustrations and voice. Kathryn Matthews studied the interactive CD-ROM aided teaching software in reading comprehension training (Matthews, 1997), and pointed out that the learners in experimental group who read stories based on CD-ROM retold the stories far more completely than those in the contrast experimental group who read paper-based stories, which shows that learning based on CD-ROM can make learners realize text interaction, and actively build the text so as to comprehend the text.

There is no doubt that some successful cases of the multimedia aided English teaching also exist in China.

In 1999, Shi Huifeng, a teacher in the department of foreign languages in Xiangfan College in Hubei carried out the experimental studies of "the application of multimedia in British and American literature teaching" (Shi, 2003), showing that using the courseware can improve the students' study effect, cultivate their interest in English and American literature and get rid of the fear of foreign literature. In Northwestern Polytechnical University, Zhao Shuanke and Yang Hong also probed into the multimedia aided foreign language teaching. Selecting non-English major graduate students as objects of study, they used multimedia-aided English teaching to teach them for a term. The research showed that multimedia English teaching has a lot of advantages. First, it can improve students' English ability, and make teaching vivid. Second, it can subtly raise the students' ability of applying language and improve the quality of English teaching. In addition, it can save valuable class time, increase the class information and fundamentally improve the efficiency of teaching (Zhao, 2006).

In a word, from the overview of literature we can know clearly that multimedia has been employed in English teaching. But have the teachers in different schools at all levels really recognized the importance of multimedia-aided teaching and used it? What is the current situation of the rural junior English teaching?

\section{The Current Situation of the Rural Junior English Teaching}

Although multimedia-aided English teaching is a frequently heard phrase and many teachers have employed it, yet many English teachers in rural junior middle school are so used to employing the traditional teaching methods that they often neglect the following.

\subsection{Neglecting the Expressional Function of Language}

As is known to all, language has two systems - expression form and expression function. The traditional teaching overemphasizes the form, but ignores the expressional role of language. Traditional English teaching generally follows this English teaching process: "new words - text - grammar — practice". The process can help students to lay a more solid foundation for learning language. However, our students do not know how to use English after reciting a lot of rules and remembering a lot of words and phrases. They even cannot make a simple conversation after learning English for several years.

Some time ago, a survey about the English level of students in different countries showed that the English level of Chinese students ranked the 48th among 52 countries. Besides, some Chinese students in foreign countries are very scared to answer the phone and scared to take part in any discussion. These illustrate that the traditional English teaching has serious drawbacks. It not only cultivates "dumb English", but also wastes a lot of time. On the contrary, with the same cultural background, students from Hongkong, Maco and Taiwan are inferior in grammar and language, but they speak and practice again and again. They do not fear to make mistakes or to be laughed at for the mistakes. So they soon reap the benefits of using the sentences they have learned to communicate with others.

To educate all students and stress quality-oriented education is the basic aim of the National English Curriculum Standards. The new standards "take care of students' affective needs as well as other needs" (Wang, 2006). Aimed at the common phenomenon of "the dumb or the deaf English", which means that students can only recognise English words but can't express themselves or understand others, New Standard for Teaching Objectives puts forward specific requirements: To cultivate students to have strong reading ability and some 
ability in listening, speaking, writing and translating in order to communicate information in English. In fact, a majority of students don't have the ability to use the language. They even have difficulty in dealing with their daily communication, let alone meeting the specific requirements of the New Standard for Teaching Objectives. For the sake of passing the state entrance examination, many students spend a lot of time in studying English every day and every thing making way for the learning of English nearly becomes a general phenomenon in our country. But in spite of the fact that students do a lot in learning English, many of them haven't achieved their desired results.

\subsection{Neglecting the Main Role of Students}

For a long time, the foreign language teaching in our country follows the principle of teacher as the center. The quality of teaching is measured by whether the teachers have well prepared their lessons or have well organized their lectures clearly, logically and with rich information, so the teachers take most of the time to explain the language points, grammar rules and so on, while the students have few opportunities to practice. As a result, students turn out to be passive receivers of the language knowledge.

Actually, the primary task of learning English is "learning" instead of "teaching". Constructivists think "Effective language teaching should not be contrary to the natural process, but should fit in the natural process; it should not block up learning, but should devote to learning and to promoting learning; it does not enable students to adapt to the teachers and textbooks, but it should make teachers and textbooks fit in students." However, in the rural junior English teaching, the process is completely different. Teachers emphasize "teaching" instead of "learning". They can't discover and solve students' problems in time while students cannot become the true masters of learning English. Unlike learning other basic subjects, to learn English well, students need to practice and practice. They should not be afraid of making mistakes. In fact, learning English as a foreign language is, to some extent, a process of making and correcting mistakes. The teaching effectiveness depends on students' learning effectiveness, while learning effectiveness largely depends on the initiation and participation of students. Therefore, the teaching have to be student-centered, so that class will be filled with vigor and enthusiasm.

\subsection{Neglecting the Cultivation of Students' Thinking in English}

There are significant differences in thought pattern between different ethnic groups. But the English teachers in rural junior middle school tend to ignore the differences between the Chinese thought and English thought.

As is known to all, communication is the goal of learning a language. But how to express ourselves clearly in communication can be different from person to person, and from nation to nation. In communication between two persons from different countries, we can very often see embarrassment in mutual understanding, even if both of them are trying to speak simply and briefly. The problem stems from more than a mere difference between words or symbols. It is also a matter of the arrangement of words together in a sentence. The words in one language do not fit together in the same way as the words of another language do. More importantly, the ideas offered by words do not fit together in the same way from language to language. These differences exist because each nation has its special way of thinking determined by its own culture.

Generally speaking, the English thought pattern has a basic feature of straightforwardness. The British people and American people, especially the Americans, developed their culture under the condition of a worldwide rapid development of economy. "Time is money" became their motto in capital accumulation. Then, they would try every possible means to save time in voicing their opinion in doing business. By and by, they formed the direct way of thinking (Shi, 2010). However, Chinese thought is the Oriental circling pattern. Our nation, known as one of courtesy, enjoys a five-thousand-year history. Early in the fourth century before Christ, Confucius, the great thinker and educator of us asked his students to be always friendly with each other and to avoid offending others whenever they spoke or wrote, even for criticism. His students taught more people to act the same way. By and by, in the long run of history, our nation formed a way of circling thinking.

In the rural junior English teaching, teachers just teach the language itself. They, to a great extent, do not attach importance to the influence of thinking, which has a bad effect on students' communication with others.

\section{Applying Multimedia in Rural Junior English Teaching}

\subsection{Using Multimedia to Build Students' Knowledge Structure}

In English teaching, creating teaching scenarios is a way to cultivate students' thought of image and improve teaching efficiency. It helps students not only to acquire knowledge and skills easily, but also to better experience 
the teaching process. If we use multimedia technology to carry out teaching, we can provide students with illustrations, audios and videos, which will give students a more intuitive feel so as to improve the teaching efficiency and help students quickly build their knowledge structure.

Suppose we teach "Western Music" in Module 5 of Student's Book 3. If teachers only tell students that western music includes blues, classical, jazz, opera, pop, rock and techno and then tell them what is blues, classical, jazz, opera, pop ,rock and techno, students maybe only know the types of western music but have no idea of what each kind of music is like and how one kind of music is different from the other. However, if teachers present the different kinds of western music with the help of audios and videos, students may have a better understanding and a lasting memory.

\subsection{Using Multimedia to Stimulate Students' Interest in Learning English}

Psychological theories tell us that interest is an emotion with a positive effect, and the human emotion is always created in a certain situation. In the process of English teaching, teachers' creating teaching scenario with the help of multimedia is helpful to present the teaching information vividly and straightforwardly to the student. The multimedia is a combination of pictures and words; a combination of sounds and feelings; a combination of audios and vision. The experiments of modern psychology indicated that during the teaching process, the application of voice, videos and images in multimedia courseware can redeploy students' hands, eyes, mouth, and other organs to take part in learning, and to maintain the brain clear, which can provide good environment for students to finish learning tasks. Much research has been done, and "Research has shown striking improvements in many types of memory tasks when people are asked to visualize the items to be remembered" (Hou, 2012). Therefore, teachers can create a colorful, synchronization of audio and video and dynamic scenes for students with the aid of multimedia, which can present the teaching content vividly in front of students, and can effectively make the atmosphere of class active. Moreover, it is helpful to arousing student's interest in learning and their desire to explore.

Suppose we teach "Journey to Space" in Module 3 of Students' Book 3. If the teachers just say "The Earth is a planet and it goes around the Sun. Seven other planets also go around the Sun. None of them has an environment with air, so people and things cannot grow. The Sun and its planets are called the sollar system. The solar system is a small prat of our galaxy," students may feel puzzled and have no idea of what the solar system is like and as a result they may completely lose interest to analyze what the teachers aim to express. However, if teachers use pictures and videos to show what the solar system is like and how the planets go around the Sun, the students may be eager to know more about the planet and be interested in the solar system.

\subsection{Using Multimedia to Enrich Teaching Content}

It is well known that combined with the multimedia-assisted English teaching, the traditional English teaching can become more colorful, vivid, innovative and informative. Besides, with the aid of multimedia-aided English teaching, it will be much easier for us to vary the teaching modes and methods and to cultivate students' independent learning consciousness.

Suppose we teach "Lao She Teahouse" in Module 10 of Students's Book 3. If teachers just say "The play shows the audience life in China from 1898 to 1945. It takes place in a teahouse in old Beijing and it tells us the story of Wang Lifa and his customers. It asks us to see the teahouse as the center of the neighborhood," students may have no idea what the life in old China was like and what the teahouse was like and so on. But if teachers play some videos about Lao She Teahouse, students can easily understand what they want to know and learn more about Lao She Teahouse and the common people's life in the past..

\subsection{Using Multimedia to Improve Teaching Efficiency}

In English teaching, we can improve learning efficiency through the multi-level, high-capacity and multi-angle exercises from the program design when we use the multimedia to aid the English teaching.

In the multimedia-aided English teaching, the teachers can demonstrate the logical structure of the text intuitively and vividly as long as they click the mouse in a short time, which is good for cultivating the students' abilities of liatening, reading, speaking and writing. At the same time, teachers can save a lot of time to teach. Therefore, the basic knowledge can be explained in more detail. Besides, with the aid of multimedia, the capacity of practice can be larger and the content of teaching can be more interesting. Most importantly, the multimedia-assisted English teaching can provide a solid foundation for the students' consolidation of new knowledge. What is more, this kind of teaching can provide extra protection for alleviating the heavy academic 
burden on students.

Multimedia-assisted teaching helps to improve teachers' quality. The use of multimedia can organically connect all teaching links. Teachers can know the knowledge system more clearly, and master the knowledge more accurately. It is almost an equivalent to a re-learning of knowledge, which can effectively improve and enrich teachers themselves.

Although multimedia-aided junior English teaching has a lot of advantages, we still have something to keep in mind in order to achieve a better teaching efficiency when applying multimedia in English teaching in rural junior school.

\section{Things to Keep in Mind When Applying Multimedia in Rural Junior English Teaching}

\subsection{Combining Multimedia-aided Teaching with Traditional Teaching}

As is known to all, every coin has its two sides. Multimedia-aided teaching and the traditional teaching also have their respective advantages and disadvantages. The traditional English teaching can provide a solid foundation for the basic knowledge such as grammar and vocabularies, while the multimedia-aided English teaching can arouse the students' learning interest and enrich the content. Therefore, the best way to improve the quality of English teaching and learning is to combine the two.

But before teaching, teachers should fully take teaching contents and students' learning ability into account in order to choose proper teaching strategies and teaching methodologies. On the one hand, with the use of simple spoken language and clear blackboard writing, teachers can achieve their teaching objectives by using proper body language. On the other hand, teachers can apply multimedia material with interesting pictures, songs or videos. They are more likely to attract students' attention and make them immersed in English learning.

In a word, utilizing the advantages of traditional English teaching and the progress of multimedia-aided English teaching, teachers can enhance their teaching efficiency. And if we combine multimedia-aided teaching with traditional teaching, English teaching can develop in the right direction.

\subsection{Offering Moderate Amount of Information in Each Period}

Multimedia can present lots of information in the meantime, which is one of the advancement of multimedia. However, in some aspects, if teachers offer much information that students cannot comprehend and accept, it can also lead to serious consequences. Teachers should have a good understanding of the teaching contents and have a appropriate plan before class, because, unlike grown-ups, junior students' ability of accepting and understanding knowledge is limited. They should determine what and how much should be taught in a class taking into account of the difficulty of the teaching material and students' English ability. They should be fully aware of students' limited cognitive abilities and try to avoid offering too much information in a class.

\subsection{Offering Moderate Amount of Stimulating Material}

Stimulating material is frequently used as a lead-in to stimulate students' interest in and imagination about the topic concerned.

But sometimes, teachers have the misconception that the more stimulating material is offered in a class, the more efficient their teaching is. It is true that moderate stimulating material can easily appeal students' attention, but it is also true that too much stimulating material may distract students' attention and increase their burden.

As far as the teachers are concerned, the stimulating material is used to boost the effectiveness of the class, not to shorten the effectiveness of the class. As far as the students are concerned, they have to study contents related to the textbook, rather than contents that have bad effects on them. Therefore, the stimulating material must be offered moderately when teachers use multimedia to aid English teaching. Teachers should avoid offering too much stimulating material to distract students' attention such as sounds, pictures and images.

\subsection{Stressing Students' Main Role in Learning and Teachers 'Guiding Role in Teaching}

In the multimedia-assisted English teaching, it is common that many teachers often have the misconception of teachers' and students' role in teaching and learning English. The class effectiveness is decided by the interaction between teachers and students, but not determined by the teacher. To a great extent, the success of teaching depends on teachers' guiding and students' autonomous learning. The teaching goals should be finished by the interaction between teachers and students. The teaching and learning process should be following: teachers' transferring information to students--students' accepting and digesting the information--teachers' getting 
feedback from students. The teaching process can be finished successfully if teachers and students can participate in the class posotively. So teachers should have a clear conception of students' and teachers' role in class when using multimedia in English teaching. It's significant to emphasize teachers' guiding role in teaching English and students' main role in learning English.

\section{Conclusion}

Using multimedia in English teaching is the direction of reform and main stream in English teaching. Compared with the traditional English teaching, the multimedia-aided English teaching has its incomparable superiority in developing students' slills of English. Under the present circumstances, teachers, especially those in rural junior high schools, should attach importance to applying multimedia in English teaching and provide students with an audio-visual language learning environment. When applying multimedia, teachers should combine multimedia-aided English teaching with traditional English teaching and offer moderate amount of information and stimulating material. Besides, teachers should take into account the characters and interests of students and their learning ability and emphasize their main role in English learning. With all above factors considered, we can apply multimedia in an appropriate way in rural junior English classes. In that case, we can get more satisfying results with a certain of effort, and the teaching efficiency and teaching quality can be improved significantly.

\section{References}

Andrew, G. (1998). English Teaching and Media Education. Buckingham [England]: Philadelphia: Open University Press.

Huang, H. (2003). Modern Education Technology. Chengdu: Sichuan Education Press.

Matthews, K. (1997). The Influence of Interactive CD-ROM Storybook on Reading Comprehension. Journal of Research on Computerizing in Education, 263-70.

Shi, J., \& Shuai, P. (2010). English Writing. Beijing: Foreign Language Teaching and Research Press.

The Ministry of Education, China. (1993). English Syllabus for Nine-Year Compulsory Education in Full-Time Junior Secondary School. Beijing: People's Education Press.

The National English Curriculum Standards for Nine-Year Compulsory Education (Revised Version). (2011). Beijing: Beijing Normal University Press.

Wang, Q. (2005). English Language Teaching. Beijing: High Education Press.

Wang, Q. (2006). A Course in English Language Teaching. Beijing: Higher Education Press.

\section{Copyrights}

Copyright for this article is retained by the author(s), with first publication rights granted to the journal.

This is an open-access article distributed under the terms and conditions of the Creative Commons Attribution license (http://creativecommons.org/licenses/by/3.0/). 